\title{
Pengembangan Media Pembelajaran Interaktif 3 Dimensi untuk Pembelajaran Materi Pengenalan Lingkungan Pada Anak Usia Dini di Indonesia.
}

\author{
Dhega Febiharsa ${ }^{1}$ Djuniadi $^{2}$ \\ Mahasiswa Magister Pend. Kejuruan PPs UNNES 12 \\ febiharsa@gmail.com ${ }^{1}$ djuniadi@mail.unnes.ac.id ${ }^{2}$
}

\begin{abstract}
Pengenalan objek-objek dalam alam semesta seringkali hanya diberikan sebagai gambar dua dimensi kepada anak usia dini, sehingga anak tidak dapat mengetahui bentuk objek secara nyata. Pengembangan media ineraktif 3 dimensi ditujukan untuk memberikan gambaran tentang materi secara visual dari berbagai sisi. Objek berbahaya bagi anak usia dini seperti api, air terjun, sungai mampu divisualkan dengan media ini dengan lebih detail dan nyata. Pemanfaatan aplikasi pembuat game Unity sebagai sarana dalam pembuatan media pembelajaran untuk anak usia dini dirasa cukup mempermudah dalam pembuatan media pembelajaran dengan tema Pengenaan Alam Semesta dan Lingkungan Sekitar. Pengembangan media dilakukan dengan metode research and development, dengan uji validitas oleh ahli media, dan uji pengguna. Hasil dari penelitian berupa media pembelajaran interaktif 3 dimensi yang dapat digunakan sebagai bahan ajar guru sekaligus sebagai sumber belajar bagi anak usia dini.
\end{abstract}

\section{Kata Kunci: pembelajaran, multimedia, 3 dimensi, Anak Usia Dini}

The introduction of objects in the universe is often the same as a two-dimensional image to an early child, so that the child can not know the real shape of the object. The development of 3dimensional inertial media is intended to provide a visual representation of the material visually from all sides. Objects harmful to early childhood such as fire, waterfall, river can be visualized with this media with more detail and real. The utilization of Unity game maker application as a tool in making learning media for early childhood is considered quite easy in making learning media with the theme of the Implementation of the Universe and the Environment. Media development is done by research and development method, with validity test by expert media, and user test. The results of the research in the form of interactive 3-dimensional learning media that can be used as teacher learning materials as well as a source of learning for young children.

Keywords: multimedia, learning, 3 dimensions, early childhood 


\section{PENDAHULUAN}

Pendidikan anak usia dini merupakan salah satu bentuk pendidikan yang menitikberatkan pada peletakan dasar ke arah pertumbuhan dan 5 perkembangan anak, yaitu : perkembangan moral dan agama, perkembangan fisik (koordinasi motorik halus dan kasar), kecerdasan/kognitif (daya pikir, daya cipta), sosio emosional (sikap dan emosi) bahasa dan komunikasi, sesuai dengan keunikan dan tahaptahap perkembangan sesuai kelompok usia yang dilalui oleh anak usia dini seperti yang tercantum dalam Permendiknas no 58 tahun 2009. Rentangan anak usia dini menurut Pasal 28 UU Sistem Pendidikan Nasional Nomor 20 Tahun 2003 ayat 1 adalah 0-6 tahun. Sementara menurut kajian rumpun keilmuan PAUD dan penyelenggaraannya di beberapa negara, PAUD dilaksanakan sejak usia 0-8 tahun (masa emas). Ruang Lingkup Pendidikan Anak Usia Dini dibagi menjadi : (1) Infant, anak usia 0-1 tahun, (2) Toddler, anak usia 2-3 tahun, (3) Preschool/ Kindergarten children, anak usia 3-6 tahun, dan (4) Early Primary School (SD Kelas Awal) (usia 6-8 tahun). (wikipedia.org, diakses 1 Juli 2015)

Standar tingkat pencapaian anak usia dini yang harus dicapai berdasarkan Permendiknas Nomor 58 Tahun 2009, salah satu diantaranya adalah Pengetahuan umum dan sains, yang meliputi: Mengenal benda berdasarkan fungsi (pisau untuk memotong, pensil untuk menulis); Menggunakan benda-benda sebagai permainan simbolik (kursi sebagai mobil); Mengenal gejala sebab-akibat yang terkait dengan dirinya; Mengenal konsep sederhana dalam kehidupan sehari-hari (gerimis, hujan, gelap, terang, temaram, dsb); dan Mengkreasikan sesuatu sesuai dengan idenya sendiri. Salah satu upaya dalam pengenalan tersebut dapat ditempuh dengan menggunakan media pembelajaran interaktif 3 dimensi.

Menurut Daryanto (dalam Hastuti, 2011) menyatakan bahwa media 3 dimensi merupakan sekelompok media tanpa proyeksi yang penyajiannya secara visual tiga dimensiona. Sedangkan menurut wikipedia (id.wikipedia.org/wiki/3_dimensi), 3 dimensi atau 3D adalah bentuk dari benda yang memiliki panjang, lebar, dan tinggi. Istilah ini biasanya digunakan dalam bidang seni, animasi, komputer dan matematika. Hastuti (2011) menyatakan bahwa, menurut batasan-batasan dari para ahli, media animasi 3 dimensi adalah suatu bentuk penyajian informasi dengan menggunakan teknik visualisasi dengan program komputer yang menampilkan gambar statis yang dibuat seolah-olah bergerak sehingga mempunyai kesan yang lebih nyata seperti benda asli.

Media pembelajaran interaktif 3 dimensi merupakan media yang memungkinkan virtualisasi objek pembelajaran ke dalam komputer. Teknologi virtualisasi 3 dimensi telah banyak dikembangkan untuk simulasi berbagai kebutuhan baik itu di bidang arsitektur, rancang bangun sistem, dan lain sebagainya. Teknologi ini memungkinkan representasi obyek ditampilkan secara vitual kepada pebelajar.

Pemanfaatan teknologi 3 dimensi di bidang pendidikan anak usia dini merupakan salah satu upaya untuk menghadirkan lingkungan virtual dalam pengenalan objek-objek yang tidak memungkinkan dihadirkan dalam kelas atau adanya resiko-resiko tertentu bagi anak usia dini. Anak tidak perlu datang langsung ke objek asli, namun anak sudah dapat mengetahui bentuk objek secara 3 dimensi secara virtual di hadapan komputer. Objek-objek berbahaya bagi anak usia dini seperti air tejun, sungai, gunung, dan sebagainya dapat dipelajari tanpa harus datang langsung ke objek yang bersangkutan, sehingga dengan media ini anak dapat mengetahui dengan persis bagaimana bentuk dari objek tersebut.

Pengembangan media 3D untuk anak usia dini ini akan memperoleh hasil yang lebih optimal bila dilakukan dengan kolaborasi antara game designer, ahli media dan praktisi pendidikan usia dini. Hasil dari penelitian ini merupakan data kualitatif yang nantinya dapat dijadikan rujukan dalam pengembangan media pembelajaran berbasis 3 dimensi di kemudian hari.

Media pembelajaran berbasis dunia virtual ini diharapkan dapat cukup membantu dalam menjawab rasa ingin tahu anak usia dini tentang lingkungan sekitar tanpa harus melakukan kunjungan ke objek sesungguhnya, yang mungkin sulit untuk dilakukan di dunia nyata. Kolaborasi ini akan menghasilkan media yang lebih representatif, menarik dan mampu memperhatikan aspek-aspek estetika, aspek 
rasional, aspek psikologis, maupun aspek non teknis lainnya, sesuai dengan model pembelajaran yang sesuai.

Menurut Sujiono (dalam Hayati, 2011), terdapat dua jenis model pembelajaran pada anak usia dini, yaitu model pembelajaran yang berpusat pada guru dan model pembelajaran yang berpusat pada anak. Sedangkan model pembelajaran yang berpusat pada anak terbagi menjadi model pembelajaran kelompok dan model pembelajaran berdasarkan minat.

Model pembelajaran kelompok atau Cooperatif Learning merupakan pembelajaran yang berupaya membantu anak didik untuk mampu mempelajari materi belajar dan berbagai keterampilan untuk mencapai tujuan dan sasaran sosial serta interaksi dengan orang lain. Sedangkan model pembelajaran minat adalah pembelajaran yang memberikan kesempatan bagi anak didik untuk memilih atau melakukan kegiatan sendiri sesuai dengan minatnya. Pembelajaran berdasarkan minat dirancang untuk memenuhi kebutuhan-kebutuhan spesifik anak. Media interaktif 3 dimensi merupakan media yang dirancang untuk pembelajaran minat, artinya memfasilitasi anak untuk melakukan kegiatan sendiri dalam mengeksplorasi apa yang ingin diketahuinya dengan konten yang ada dalam media pembelajaran yang dirancang atau didesain.

\section{KAJIAN TEORI}

\section{Desain Media}

Cara untuk menentukan desain media pembelajaran adalah untuk menggambarkan proses yang terlibat dalam perencanaan sistematis pembelajaran. Mulai pada tingkat yang paling dasar, pekerjaan desainer pembelajaran dalam menjawab tiga pertanyaan utama (Mager, 1984) dalam (Smith dan Ragan, 1999): (1) Kemana kita akan pergi? (Apa tujuan dari pembelajaran?), (2) Bagaimana kita akan sampai di sana? (Apa strategi pembelajaran dan media pembelajaran?), (3) Bagaimana kita akan tahu kapan kita telah tiba? (Apa yang harus pengujian kami terlihat seperti? Bagaimana kita akan mengevaluasi dan merevisi bahan ajar?)

Ketiga pertanyaan dapat dimulai sebagai kegiatan utama yang desainer pembelajaran harus lengkapi selama proses desain dan pengembangan: a) Lakukan analisis instruksional untuk menentukan "di mana kita akan pergi.", b) Mengembangkan strategi instruksional untuk menentukan "bagaimana kita akan sampai di sana.", c) Mengembangkan dan melakukan evaluasi untuk menentukan "bagaimana kita akan tahu ketika kami berada di sana." (Smith dan Ragan, 1999)

\section{Media 3D}

Beberapa kegiatan utama tersebut dijadikan dasar dalam proses pembuatan media pembelajaran 3 dimensi.

Konteks 3D dibangun di atas pengetahuan dunia nyata peserta didik dengan memberikan metafora visual, atau narasi visual, dari isi materi pembelajaran. Hal ini menyediakan tempat untuk belajar yang akrab dan menarik (Dickey, 2005) dalam (Bronack, et al, 2008). Media pembelajaran semacam ini mampu membuat pebelajar merasa di dunia yang berbeda, namun tetap familiar dan menarik. Media 3 dimensi akan membuat pengguna seolah-olah berada di kehidupan yang sebenarnya.

Pembuatan media 3 dimensi dalam pembelajaran dilakukan dengan menggunakan aplikasi khusus yang lazim digunakan dalam membuat sebuah permainan (game) yang disebut sebagai game engine. Aplikasi inilah berperan sebagai alat dalam pengembangan media interaktif 3 dimensi sebagai penunjang seorang desainer game atau media pembelajaran 3 dimensi. Tjahyadi, dkk. (2014) menyatakan bahwa, Game engine merujuk pada kumpulan modul kode simulasi yang secara tidak langsung menentukan perilaku sebuah permainan (game logic) atau lingkungan permainan (level data). Game engine mencakup modul 
untuk menangani input, output (3D Rendering, gambar 2 Dimensi, dan suara atau soundtrack) dan generic physics atau dinamika untuk dunia game.

Di pasaran tersedia banyak game engine yang dirancang untuk bekerja pada konsol video game dan sistem operasi desktop seperti Microsoft Windows, Linux, dan Mac OS. Fungsi utama yang dari sebuah game engine pada umumnya adalah sebagai renderer (pembentuk objek/material baru) untuk grafis 2 dimensi atau 3 dimensi, suara/audio, script (bahasa pemrograman), animasi, kecerdasan buatan (artificial intelligence), jaringan, streaming, manajemen memori, threading, dukungan lokalisasi, dan adegan grafik. Sebuah game engine biasanya menyediakan platform abstraksi, yang memungkinkan permainan yang sama untuk dijalankan pada berbagai platform termasuk konsol game dan komputer pribadi dengan perbedaan yang tidak signifikan. Game engine membantu dalam membuat keputusan untuk menentukan frame sampai menentukan artwork yang ada di dalam suatu scene dalam sebuah game. (Tjahyadi, dkk. 2014) Salah satu aplikasi game engine yang digunakan dalam pengembangan media interaktif 3 dimensi untuk anak usia dini adalah Unity $3 D$.

Unity $3 D$ atau dikenal juga dengan Unity, merupakan aplikasi pembuat permainan (game) komputer 2 dimensi maupun 3 dimensi yang diluncurkan oleh Unity Technologies pada tahun 2005. Aplikasi ini memiliki kemampuan dalam membuat game dengan berbagai platform, seperti PC, Android, Web Player, dan sebagainya. Objek-objek 3 dimensi dapat dianimasi dan dikendalikan dengan pemrograman atau kode-kode khusus (C++, JavaSript dan sebagainya) menjadi objek game yang dapat saling bertumbukan atau gerakan-gerakan lainnya dalam sebuah permainan komputer. Aplikasi ini juga memberikan kemudahan yang lebih tinggi dibanding aplikasi game engine lainnya. (Pranata, Baskara Arya, dkk. 2014) Kode-kode pemrograman ditambahkan dalam proses pembuatan media dengan Unity agar permainan dapat dikendalikan dengan kontrol perangkat komputer.

Creighton (2010) menyatakan, kode merupakan serangkaian instruksi yang diberikan kepada Unity untuk melakukan aksi tertentu. Baris-baris kode dituliskan untuk mendefinisikan apa yang akan dikerjakan dalam game. Baris kode ini disebut dengan statement (pernyataan). Unity membaca statement-statement ini dan mengubahnya menjadi instruksi. Di Unity biasanya programmer atau desainer game menggunakan sekumpulan instruksi dan menempelkannya (meletakkannya) pada game object. Sejalan dengan itu, Blackman (2011) menyatakan bahwa Script (kode-kode pemrograman) dapat berisi setiap jumlah informasi dan instruksi. Tantangan bagi seorang game designer adalah menjaga script yang digunakan terorganisir sehingga mesin permainan akan tahu bagaimana dan kapan harus menggunakan informasi atau instruksi. Tantangan lain dalam membuat script adalah memutuskan di mana untuk menempatkan script.

Selain aplikasi game engine, bagian yang tak kalah penting dalam menyusun media pembelajaran adalah menyusun sebuah storyboard, yang akan membantu dalam penyusunan alur cerita sebuah media pembelajaran. Seperti halnya membuat sebuah film, pembuatan media pembelajaran juga memerlukan sebuah storyboard untuk memudahkan desainer media dalam mewujudkan ide-ide dalam scene-scene dalam media pemebelajaran yang akan dibuat. Storyboard adalah penyelenggara visual, biasanya merupakan serangkaian ilustrasi yang ditampilkan dalam urutan untuk tujuan mem-pra-visualisasikan tayangan video, pelatihan berbasis web, atau urutan media interaktif. Soryboard diperkenalkan pertama kali oleh Walt Disney di tahun 1930-an, di tahun setelah itu hampir semua produksi film mayoritas sudah menggunakan storyboard. (Rector, 2013).

\section{METODE}

Metode yang digunakan dalam penelitian ini adalah Research and Development dengan objek adalah Media Pembelajaran dan subjek peneitian adalah Pengguna. Subjek penelitian adalah anak usia dini dan guru pengajar di Pendidikan Anak Usia Dini (PAUD) Laboratorium "Belia". Penelitian dilakukan 
melalui beberapa tahap, yaitu penelitian pendahuluan berupa observasi kurikulum di PAUD Laboratorium Belia, untuk dasar penyusunan konten media. Observasi dilakukan dengan wawancara dan pengumpulan data tertulis berupa Rencana Kegiatan Harian (RKH) PAUD. Menurut Astuti (2011), Rencana Kegiatan Harian (RKH) merupakan penjabaran dari Rencana Kegiatan Mingguan (RKM). RKH terdiri atas kegiatan pembukaan, kegiatan inti, istirahat/makan, dan kegiatan penutup. Data RKH yang didapatkan, selanjutnya dijadikan dasar dalam perancangan dan pembuatan media.

Proses pembuatan media diawali dengan membuat storyboard sebagai perencaaan visual yang akan disajikan dalam media. Alur di sini bersifat pilihan, pengguna dapat mealui alur yang berbeda satu sama lain, dikarenakan pengguna dapat menentukan alur sendiri sebagai pelaku dalam media (game), pengguna bebas bergerak ke manapun di dalam lingkungan game (dunia virtual) media pembelajaran. Secara teknis pembuatan media dilakukan dengan aplikasi Unity 3D versi 4.0.0 dengan terlebih dahulu membuat Terrain atau menurut Pranata, dkk. (2014), sebagai bentuk permukaan bumi, bukit, embah, pegunungan, bahkan lautan. Kemudian meletakkan game object ke dalam scene dunia virtual yang dibuat. Secara sederhana scene diartikan sebagai level pada game, tempat meletakkan berbagai macam objek (Tim Litbang Wahana Komputer, 2014). Penambahan objek-objek dalam lingkungan game dilakukan dengan fasilitas impor pada aplikasi Unity. Objek-objek (atau disebut dengan game object dan assets) tersebut terdiri dari objek pohon, air, api, bangunan, mobil, dan sebagainya. Menurut Tim Litbang Wahana Komputer (2014), game object merupakan tempat membuat level game. Game object berisi berbagai macam script (pemrograman) yang berfungsi untuk membuat karakter perilaku atau peta, sehingga dapat ditentukan cara kerja dari game yang dibuat.

Sedangkan Assset menurut Tim Litbang Wahana Komputer (2014) merupakan aspek dari permainan yang direferensikan oleh beberapa komponen, asset itu sendiri, atau kelengkapan penunjang pembuatan game. Asset terdapat secara bawaan dalam paket program aplikasi Unity 3D, dan dapat ditambahkan melalui fasilitas yang disebut Asset Store yang dapat mengunduh asset-asset lain dari internet (website penyedia asset). Roedavan (2014) menyebutkan, Asset Store merupakan etalase publik bagi seluruh pengguna Unity 3D di dunia. Sedangkan menurut Tim Litbang Wahana Komputer (2014), asset store merupakan tempat untuk mendapatkan asset yang digunakan untuk menunjang pembuatan game dengan Unity 3D.

\section{Rendering}

Selanjutnya dilakukan proses rendering terhadap game yang dibuat hingga menjadi sebuah produk media (game) yang dapat dimainkan secara terpisah (standalone) sesuai dengan kebutuhan distribusinya. Game yang telah siap digunakan merupakan produk awal yang selanjutnya divalidasi kepada ahli media.

Revisi

Tahap berikutnya, dilakukan revisi dan penyempurnaan atas masukan dan penilaian dari ahli media. Penyempurnaan yang dilakukan yaitu perubahan narasi beberapa audio objek dari yang hanya menyebutkan nama objek, menjadi nama objek kemudian diikuti pengejaan nama objek yang bersangkutan. Perubahan lainnya yaitu penambahan teks di layar berupa teks ejaan nama objek yang bersangkutan. Perbaikan produk dilakukan dengan Unity dan aplikasi perekam audio. Produk hasil revisi selanjutnya diuji kepada pengguna.

Pengguna media adalah sampel anak-anak usia dini, data didapatkan dengan lembar observasi pengamatan dan wawancara kepada sampel. Sebagai data pendukung dilakukan uji coba media kepada beberapa pengajar PAUD Laboratorium Belia (media sebagai bahan ajar guru), data didapatkan dengan menggunakan kuisioner dan lembar observasi. 


\section{HASIL PENELITIAN}

Pengembangan media pembelajaran bagi anak usia dini ini menggunakan media tiga dimensi interaktif dengan menggunakan sarana aplikasi game engine Unity 3D. Media yang dirancang untuk dapat digunakan sebagai sarana pengenalan lingkungan kepada anak usia dini. Skenario pengenalan objek dilakukan secara visual 3 dimensi dan dengan memberikan suara pada objek, yang bekerja dengan cara mengintegrasikan suara narasi yang menyebutkan nama objek ketika objek didekati oleh pengguna atau dalam hal ini disebut sebagai First Person Control (FPC). Menurut Pranata (2014), First Person Control adalah karakter utama dalam permainan. Penelitian ini menghasilkan hasil sebagai berikut.

\section{Pengembangan Media 3 Dimensi}

Pengembangan media 3 dimensi dalam pembelajaran merupakan salah satu alternatif dalam penyajian materi tematik di dunia pendidikan anak usia dini, dimana dengan media tiga dimensi diharapkan akan menambah kemampuan anak dalam memahami dan mengerti bentuk visual suatu objek dalam tema tema tertentu. Visualisasi objek secara 3 dimensi memungkinkan anak melihat objek dari berbagai sisi. Hal ini dapat merepresentasikan objek dengan lebih nyata (mendekati benda nyata). 3D Modelling dari suatu objek disajikan semirip mungkin dengan objek aslinya baik itu bentuk maupun proporsinya yang nyata di dunia sebenarnya.

Sebagai pendukung dalam pemahaman materi, sebutan nama dari objek dinarasikan dalam audio yang akan muncul (bersuara) ketika objek tersentuh atau didekati pelaku (orang pertama dalam game/media) yaitu pengguna yang memainkan (mengoperasikan) media pembelajaran ini (First Person Control).

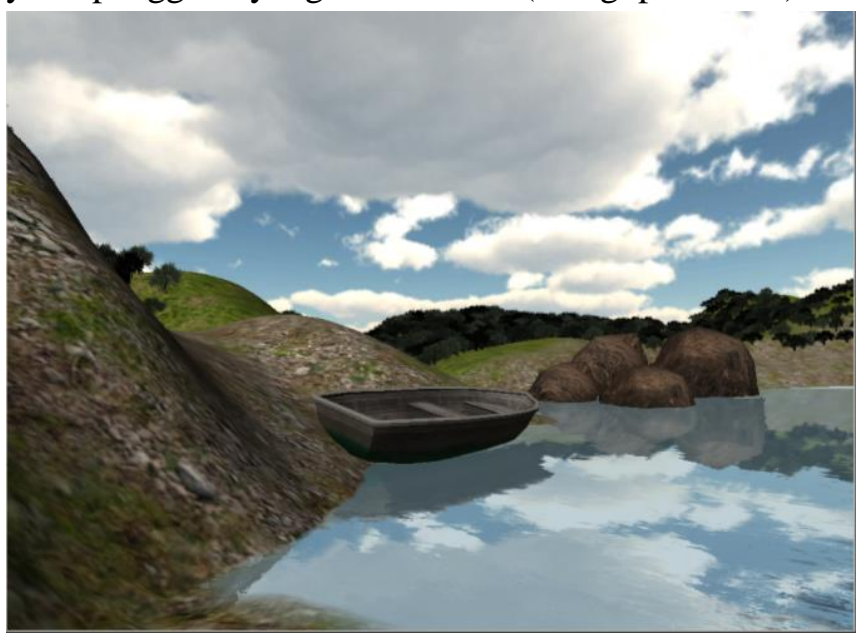

Gambar 1. Pengenalan objek (Perahu dan Sungai)

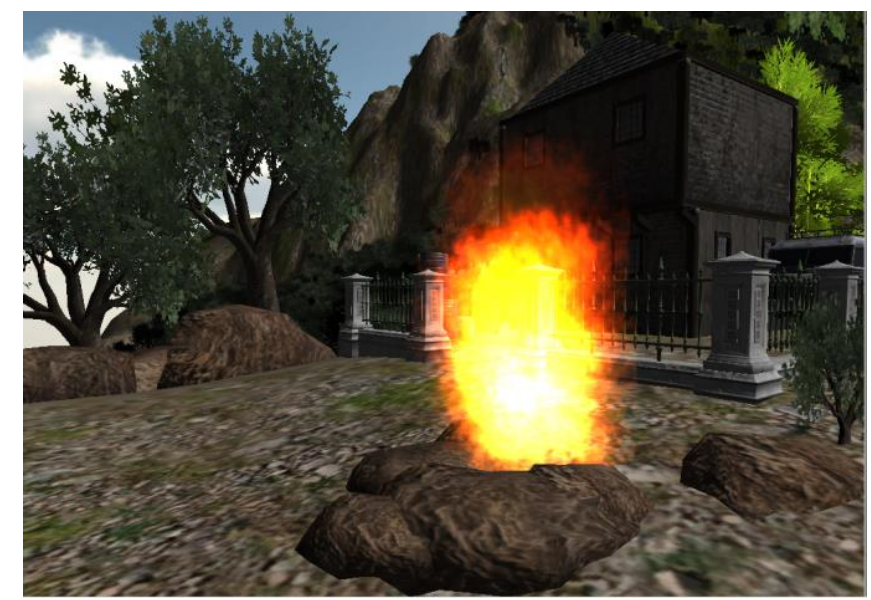

Gambar 2. Pengenalan objek (Api) 


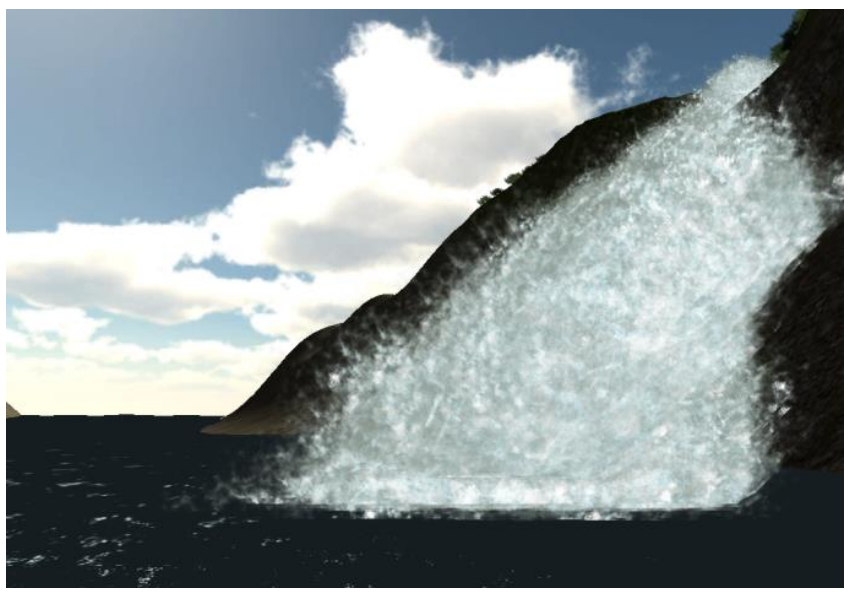

Gambar 3. Pengenalan objek (Air Terjun)

Pengenalan objek-objek berbahaya seperti api, dan objek air terjun yang mungkin dirasa terlalu berbahaya bagi anak usia dini, dapat dilakukan dengan media interaktif 3 dimensi ini tanpa harus menghadapkan langsung anak dengan api atau air terjun ke anak. Anak dapat menyusuri sungai dalam dunia virtual dan melihat refleksi yang ditimbulkan oleh air yang bergeombang, seperti halnya di dunia nyata. Suara-suara alam, gemericik air, dan suara letusan-letusan kecil yang ditimbulkan oleh benda yang terbakar oleh api dapat didengar secara 3 dimensi, seolah sedang berada di dunia atau fenomena yang sebenarnya.

Visualisai alam semesta seperti awan, matahari, gunung, bukit, lembah dapat disajikan secara virtual ke dalam media. Pohon dan dedaunan, rumput, batu, dan objek-objek yang ada di alam semesta disajikan dengan visual yang menawan dan mendekati objek yang nyata. Walaupun tidak bisa disentuh dengan indera peraba, hanya dapat ditangkap oleh indera penglihatan dan pendengaran.

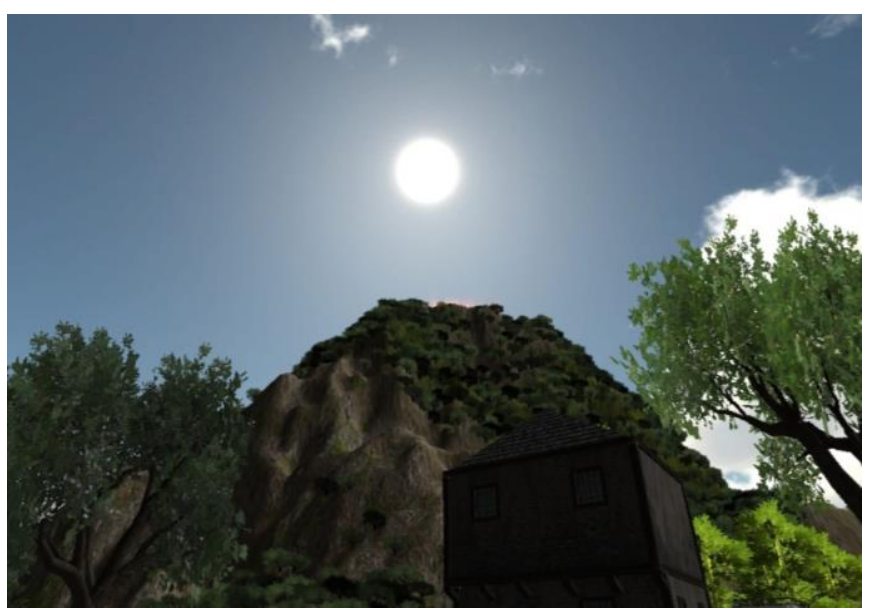

Gambar 4. Pengenalan Objek Gunung Berapi 


\section{DISKUSI}

\section{Penilaian Ahli Media}

Media 3 Dimensi ini merupakan produk awal yang digunakan untuk dapat dilakukan validasi kepada ahli media dan pengguna, apakah media yang dibuat dapat digunakan sebagai media pembelajaran secara luas. Penilaian terhadap media, dilakukan terhadap beberapa aspek. Parameter atau aspek penilaian yang digunakan dalam peniaian media sebagai uji validitas oleh ahli media meliputi: (1) Alur kerja media, (2) Kemudahan penggunan (aplikasi), (3) Kesederhanaan pengoperasian (navigasi), (4) Materi mudah dipahami, (5) Tampilan, (6) Pemilihan animasi dan karakter, (7) Kesesuaian penggunaan objek, (8) Objek yang mudah dipahami oleh anak usia dini, (9) Desain yang menarik, (10) Kesesuaian objek dan animasinya, (11) Audio dapat memperjelas materi, (12) Komposisi warna, (13) Kejelasan (detail) objek, (14) Kualitas audio (suara), (15) Tidak membosankan, (16) Kesesuaian dengan tujuan pembelajaran, (17) Originalitas, (18) Penyajian yang sistematis. Penilaian dalam lembar kuisioner menggunakan pilihan definisi nilai 1 sampai dengan 5 yang berarti: $1=$ Sangat Kurang, $2=$ Kurang, 3 $=$ Cukup, 4 = Baik, 5 = Sangat Baik, untuk masing-masing aspek, dimana total skor maksimal adalah 90 (semua dinyatakan sangat baik). Adapun hasil penilaian adalah sebagai berikut.

Tabel 1. Hasil Penilaian Ahli Media

\begin{tabular}{lll}
\hline Responden & Skor & Grade \\
\hline Ahli Media 1 & 78 & $86,67 \%$ \\
Ahli Media 2 & 69 & $76,67 \%$ \\
\hline Rata-Rata & & $81,67 \%$ \\
\hline
\end{tabular}

Hasil penilaian oleh ahli media pada Tabel 1, menunjukkan 81,67\% dari nilai maksimal, sehingga dapat dinyatakan bahwa media telah dinyatakan valid. Sehingga media layak untuk digunakan sebagai media pembelajaran untuk anak usia dini.

\section{Penilaian Pengguna}

Setelah dilakukan revisi, atas masukan dari ahli media, selanjutnya dilakukan uji pengguna untuk mengetahui respon dan kesesuaian media yang dibuat dengan tujuan pembuatan media. Penilaian oleh pengguna dibagi menjadi penilaian pengguna Guru PAUD (sebagai operator yang menggunakan media sebagai bahan ajar) dan pengguna langsung yaitu anak usia dini. Hal ini dikarenakan media dapat digunakan sebagai bahan ajar oleh guru, sekaligus dapat berfungsi sebagai sumber belajar bagi anak usia dini secara langsung. Aspek penilaian dalam uji pengguna ini diantaranya yaitu: (1) Desain visual dan estetika, (2) Kemudahan pengoperasian media, (3) Kualitas suara (audio), dan (4) Kesesuaian materi terhadap kebutuhan anak usia dini. Penilaian dalam lembar kuisioner menggunakan pilihan definisi nilai 1 sampai dengan 5 seperti halnya pada instrumen bagi ahli media. Uji pengguna Guru PAUD menghasilkan data sebagai berikut.

Tabel 2. Hasil Penilaian Media oleh Guru PAUD

\begin{tabular}{lll}
\hline Responden & Rerata Skor & Grade \\
\hline Guru PAUD 1 & 3,50 & Baik \\
Guru PAUD 2 & 4,25 & Baik \\
Guru PAUD 3 & 3,75 & Baik \\
Guru PAUD 4 & 4,00 & Baik \\
\hline Rata Rata & & \\
\hline
\end{tabular}


Berdasarkan hasil pengujian pada tabel 2, dapat dilihat bahwa media yang digunakan memiliki desain visual dan estetika yang cukup baik, cukup mudah dioperasikan oleh Guru PAUD sebagai media pembelajaran dengan adanya panduan penggunaan yang diberikan, kualitas suara cukup baik, dengan masukan perlu tambahan musik yang lebih sesuai dengan anak-anak, materi dalam media cukup sesuai dengan tujuan pengembangan media.

\section{KESIMPULAN}

Media interaktif 3 dimensi untuk anak usia dini dengan tema pengenalan lingkungan didapatkan beberapa kesimpulan. Media interaktif 3 dimensi dapat digunakan sebagai bahan ajar bagi guru Anak Usia Dini berdasarkan validasi ahli media. Media dengan tema pengenalan lingkungan sekitar dapat digunakan pula sebagai sumber belajar mandiri anak usia dini berdasarkan pengujian pengguna guru pendidikan anak usia dini.

Pengembangan media interaktif ini merupakan kolaborasi disiplin ilmu, mengingat tingkat kerumitan yang cukup tinggi dalam proses pembuatan dan pengembangan media dengan Unity 3D di tingkat Anak Usia Dini. Oleh karena itu disarankan adanya kerjasama pengembang/programmer dengan Guru PAUD atau Ahli Perkembangan Anak Usia Dini, atau dapat pula dilakukan melalui workshop maupun pelatihan pembuatan media untuk Guru PAUD sebagai sarana pengembangan bahan ajar yang lebih representatif dan efektif.

\section{REFERENSI}

Astuti, W. 2011. Hand Out MK.Perencanaan Pembelajaran AUD. Hand Out tidak diterbitkan. Malang: FIP Universitas Negeri Malang.

Blackman, Sue. 2011. Beginning 3D Game Development with Unity. New York: Apress.

Bronack, Sanders, Cheney, Riedl, Tashner, dan Matzen. 2008. Presence Pedagogy: Teaching and Learning in a 3D Virtual Immersive World. International Journal of Teaching and Learning in Higher Education, Volume 20 Number 1, 59-69.

Creighton, Ryan Henson. 2010. Unity 3D Game Deevelopment by Example. Birmingham: Packt Publishing Ltd.

Gibson, Jeremy. 2015. Introduction to Game Design, Prototyping, and Development. United States : Addison Wesley

Hatuti, Puji. 2011. Pengaruh Media Interaktif Animasi 3 Dimensi dalam Pembelajaran terhadap Prestasi Belajar IPA Anak Tunarungu Kelas D6 di SLB-B YRTRW Surakarta Tahun Pelajaran 2010/2011. Skripsi. Surakarta: Universitas Sebelas Maret Surakarta.

Hayati, Nur. 2011. Strategi Pembelajaran Anak Usia Dini. Yogyakarta: Universitas Negeri Yogyakarta.

Ibáñez, M. B., García, J. J., Galán, S., Maroto, D., Morillo, D., \& Kloos, C. D. 2011. Design and Implementation of a 3D Multi User Virtual World for Language Learning. Educational Technology \& Society, Volume 14 Nomor 4, 2-10.

Mapson, Kathleen H, Ernst, Jeremy V and Clark, Aaron C. 2012. Deveoping 3D Modeling Courses for Online Teaching: Instructional Technologies to Consider. 66th EDGD Mid-Year Conference Proceedings, 1-16. Texas: EDGD.

Mendiknas. 2009. Peraturan Menteri Pendidikan Nasional Nomor 58 Tahun 2009 tentang Standar Pendidikan Anak Usia Dini. Jakarta: Kemeterian Pendidikan Nasional.

Pranata, Pamoeji, dan Sanjaya. 2015. Mudah Membuat Game dan Potensi Finansialnya dengan Unity 3D. Jakarta: PT. Elex Media Komputindo. 
Presiden RI. 2003. Undang-Undang Republik Indonesia Nomor 20 Tahun 2003 tentang Sistem Pendidikan Nasional. Jakarta : Sekretariat Negara RI.

Roedavan, Rickman. 2014. Unity Tutorial Game Engine. Bandung: Informatika.

Smith, Patricia L and Ragan, Tilman J. 2004. Instructional Design Second Edition. Oklahoma : The University of Oklahoma.

Tim Litbang Wahana Komputer. 2014. Mudah Membuat Game 3 Dimensi menggunakan Unity 3D. Yogyakarta: Penerbit Andi.

Tjahyadi, M. P., Alicia S., Virginia T., dan Steven S. 2014. Prototipe Game Musik Bambu Menggunakan Engine Unity 3D. E-Journal Teknik Informatika Universitas Sam Ratulangi, Volume 4 Nomor 2.

Wikipedia. 2014. Pendidikan Anak Usia Dini. https://id.wikipedia.org/wiki/Pendidikan_anak_usia_dini, diakses 1 Juni 2015.

Wikipedia. 2015. 3 Dimensi. https://id.wikipedia.org/wiki/3_dimensi, diakses 7 Juli 2015. 